\title{
有翼宇宙往還機打ち上げ形態における結合部弾性モードが影響するフラッタ*1 Flutter of Winged Space Reentry Vehicles Affected by an Elastic Attachment in Launching Configuration
}

\author{
神田淳*2
}

Atsushi KandA and Tetsuhiko UedA

Key Words : Flutter, Yaw, Roll, Wind Tunnel Test, Doublet-Point Method, Reentry Vehicle

\begin{abstract}
This paper reports a flutter investigation of a re-entry space vehicle having an elastic rotational mode caused by its launching rocket. The elastic rotational mode is taken into consideration as an elastic roll mode or an elastic yaw mode. Flutter experiments were conducted in NAL Transonic Wind Tunnel. The DPM (Doublet-Point Method) is used to calculate flutter boundaries. It is shown that the elastic roll mode may lower critical flutter speed, because its existence alters the natural frequency of an anti-symmetric bending mode with which flutter occurs. A coupling between the elastic yaw mode and an anti-symmetric bending mode of a tip-fin wing is also shown to be critical.
\end{abstract}

\section{1. 序論}

我が国で，ロケットの先端に搭載されて打ち上げられる 有翼宇宙往還機 HOPE-X の計画がある .この形態におけ る往還機機体の弾性モードには, ロケットと往還機機体の 結合部やロケット自体の曲け弾性モード (以降まとめて , 結 合部の弾性モードと表記) が含まれる.本研究の目的は , 結 合部の弾性モードが機体のフラッタ特性にどのように影響 するかを調べることにある．

結合部の弾性モードは, 機体を基準にすればロール・ピッ チ・ヨー方向の回転弾性モードである (第 1 図).機体の回 転モードに対するフラッタ特性の影響については, さまざ まな研究が行われてきた . Rockwell 社と NASA Langley 研究所の共同による AFW (Active Flexible Wing) プロ グラム ${ }^{1)}$ では, ロール自由度がある場合の逆対称モードフ ラッタについて研究している. Soistmann ら²)は , ピッチ 自由度を有するリフティングボディのフラッタについて研 究した. Chen ら ${ }^{3)}$ は, ピッチ自由度を有する複合材前進 翼機のフラッタを研究した . Niblett ${ }^{4)}$ は, ピッチ自由度の フラッタへの影響を解析的に研究している.しかし，これ らはあくまでフリーフライト状態を想定したもので，回転 方向の弾性支持はない，回転弾性モードを有する場合につ いては, Kanda ら ${ }^{5,6)}$ がピッチ方向の弾性モードのフラッ タへの影響を研究している.しかし他にはほとんど研究は ない.

本論文で対象とする結合部弾性モードは, ロール弾性モー ドとヨー弾性モードである .これらの弾性モードが影響す るフラッタ特性を風洞実験で調べるためには, 模型に回転弾

\footnotetext{
*1 C 2003 日本航空宇宙学会

平成 14 年 8 月 12 日原稿受理

*2 航空宇宙技術研究所構造材料研究センター
}

性自由度を与える特殊な模型支持装置が必要である．乥こ で, ロールフリーおよびピッチ方向弾性モードの影響を調べ たときに開発した 2 種類のスティング型支持装置に改修を 加え, 光れぞれロール弾性モードとヨー弾性モードが模型 の弾性モードに含まれるようにした．支持装置に全機模型 を搭載し，航空宇宙技術研究所の遷音速風洞 TWT におい てフラッタ実験を行った . さらに , 非定常空気力に DPM ${ }^{7)}$ (Doublet-Point Method) を用いたフラッタ解析を行った ので , これらの結果を併せて報告する．

\section{2. ロール弾性モードの影響}

ロール弾性モードが影響するフラッタ特性について述べ る．フラッタ特性は風洞実験およびフラッタ解析によって 求めるが, 風洞実験を行うためには有翼宇宙往還機の打ち 上げ形態を模擬する必要がある .ここでは結合部の影響を ロール弾性モードに限定し，このモードを有する特殊なス ティング型支持装置に, 全機模型を搭載してフラッタ実験 を行った · またフラッタ解析には, DPM による非定常空 気力を用いた . 非定常空気力計算の基礎データとして振動 特性が必要であるが, これには振動試験および振動解析の 結果を用いた。

\section{1 支持装置と全機模型}

2.1 .1 支持装置 支持装置は, 以前に開発したロール自 由度を有するスティング型支持装置 ${ }^{8)}$ (改修を施し, 左右 両側にロールばねを取り付けたものである．支持装置の概 要を第 2 図に示す. 可動部はべアリングにより固定部に対 しロール方向の回転が可能であり, 模型はこの可動部に直 接取り付けられる.ロール方向の弾性は, ロールばねの曲 げ弾性により模型に与えられる．ロール弾性の特性の違い が , どのようにフラッタ特性へ影響するかを調べるために， 岡性の異なるばね (ばね A〜E の 5 種類) を用意した . ば 


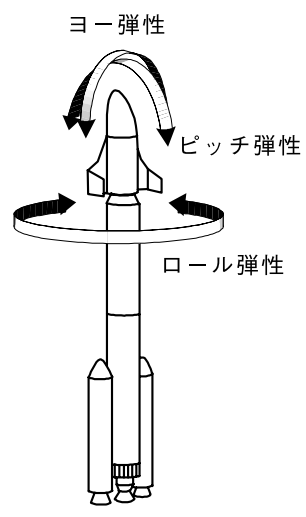

第 1 図 有翼宇宙往還機の打ち上げ形態

ねを交換することで，ロール弾性の振動特性を変えること ができる仕組みである．ただし，ばねを取り付けなければ ロール方向に弾性をもたず，ロールフリーになる．ばねに は歪みゲージを貼付した .

また，支持装置はフラッタ停止機構を内部に有する .サー ボモータにより軸に沿ってくさびを移動させることで, 可 動部を拘束し，ロール方向の回転を拘束することができる． つまり，ロール弾性モードが影響するフラッタが発生した 場合には，この機構によりロール弾性モードを拘束してフ ラッタを停止できる .

2.1 .2 全機模型 全機模型 (ロール弾性模型) を第 3 図 に示す. 模型は, HOPE-X で当初計画されていたチップ フィン形態翼を模擬したものである. 翼は主翼部とチップ フィン部とから構成される . 両部とも芯材には 7075-T651 を用い, 表面は発泡材料で成形した . 主翼部の翼根には曲 げおよびねじり計測用の歪みゲージを貼付し，風洞実験で の振動計測に用いた .

胴体部は長さ $677 \mathrm{~mm}$, 高さ・幅とも $160 \mathrm{~mm}$ である.翼 型は主翼部・チップフィン部ともに NACA0010である . 主

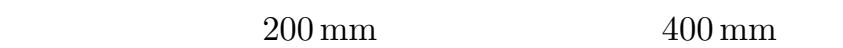
端で $120 \mathrm{~mm}$ であり，前縁および後縁クランクがスパン方 向 $80 \mathrm{~mm}$ 位置にある.チップフィン部はキャント角 $14^{\circ}$ ， スパン長は $120 \mathrm{~mm}$, 翼端コード長は $60 \mathrm{~mm}$ である.質量 は片翼で $1.3 \mathrm{~kg}$ である .

\section{2 振動特性}

2.2.1 振動試験 振動試験は, 動的変位計測システム ${ }^{9,10)}$ による自動計測で行った . 全部で 82 点（主翼部が片翼 25 点, チップフィン部が片翼 16 点) を計測し, 周波数応答関 数法により固有モードを求めた . 加振方法は動電型シェー カーによる 1 点ランダム加振である. 動的変位計測システ ム概要を第 4 図に示す . ロボットに予め計測点位置をティー チングしておくことにより, 自動で計測を行うことができ

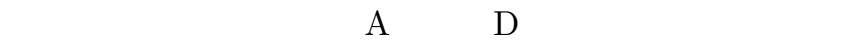
ついて，振動試験結果を第 1 表に示す。

2.2.2 振動解析 FEMによる振動解析で得られた振動特 性を第 2 表に示す . 実模型を兴のままモデル化することは困 難であったため, ビーム要素により単純化して構筑し, 質量 分布と剛性分布を実模型に近づけるチューニングを行った .

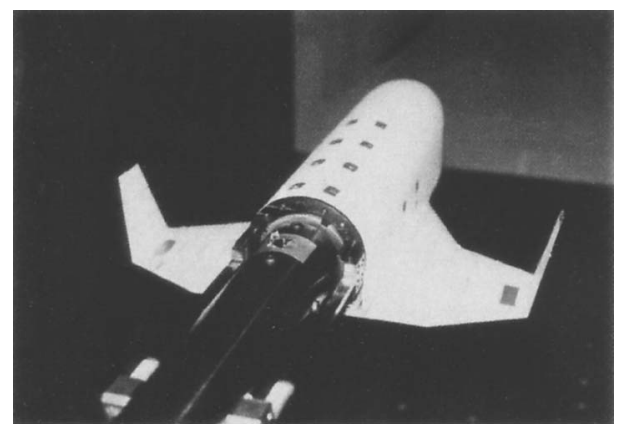

第 3 図 ロール弾性模型

2.2.3 振動特性の考察 試験と解析の結果を比較する . $1 \sim 3$ 次モードでは, 試験と解析は良く一致している.4〜8 次モードでは, 固有振動数の解析值が試験值に比べ 10 $20 \%$ 大きい .これは FEM モデルの単純化に起因すると思 われる．ただし，固有モード形は良く一致している．全体 として, ロールばねの弾性の違いは 1 次および 3 次モード に影響し，剛性が上がると 1 次， 3 次モードの振動数も上 がる。

得られた振動特性が，フラッタ解析に与える影響を考え る.フラッタ解析には固有モード形と固有振動数が必要で あり，実模型の振動特性（振動試験の結果）を用いること か望ましい.しかし実際には, 試験で精度の高い固有モ一 ド形を得ることが困難である.よって解析結果を用いるこ とになる. 固有振動数は高次モードで相違があるが, 固有 モード形は試験と解析結果が良く一致している．この原因 が解析モデルにあることを踏まえ，固有振動数として試験 值を用いることで補正する。ただし，一般的にクリティカル になるフラッタの連成モードは低次であることが多く，も ともと高次モードの影響は少ない．よって, 試験と解析結 果の相違がフラッタ解析に大きく影響しないと考えられる.

2.3 フラッタ特性

2.3.1 フラッタ実験 遷音速風洞 (測定部 $2 \mathrm{~m} \times 2 \mathrm{~m}$ ) に

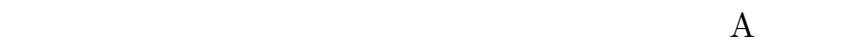
D を用いた . 風洞への模型設置概要を第 5 図に示す . 実験で は $M=0.6,0.7,0.8,1.2$ の各マッ八数で, 総圧 $P_{0}$ を低 圧から徐々に加圧する方法でクリティカルなフラッタを探つ 


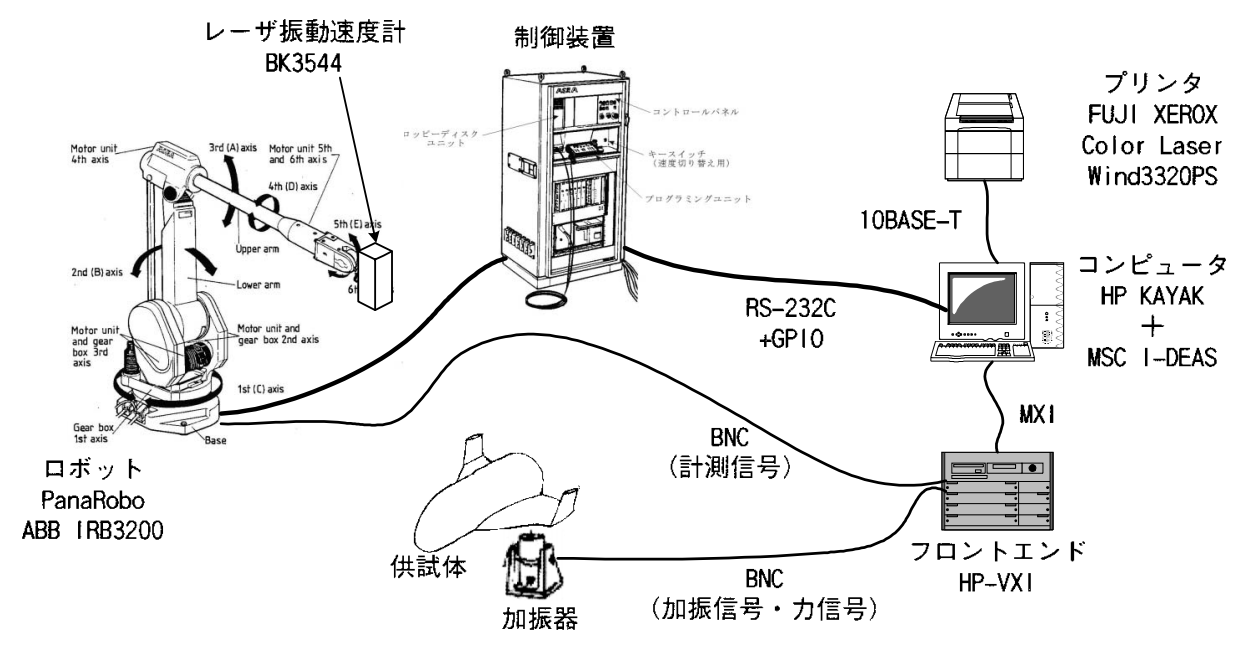

第 4 図 動的変位計測システム概要

第 1 表 ロール弾性模型の振動特性 (試験値)

\begin{tabular}{ccccl} 
& \multicolumn{3}{c}{ 第 1 表 } & \multicolumn{3}{c}{ ロール弾性模型の振動特性 (試験値) } \\
\cline { 1 - 4 } 次数 & \multicolumn{3}{c}{ 固有振動数 $[\mathrm{Hz}]$} & \multirow{2}{*}{ モード形状 } \\
\cline { 2 - 4 } & ばね $\mathrm{A}$ & ばね $\mathrm{D}$ & ばね無し & \\
\hline 1 & 21 & 40 & - & ロール弾性 \\
2 & 67 & 67 & 67 & 対称曲げ 1 次 \\
3 & 81 & 86 & 80 & 逆対称曲げ 1 次 \\
4 & 97 & 97 & 97 & 対称ねじり 1 次 \\
5 & 98 & 98 & 98 & 逆対称ねじり 1 次 \\
6 & 205 & 205 & 206 & 対称ねじり 2 次 \\
7 & 208 & 208 & 208 & 逆対称ねじり 2 次 \\
8 & 254 & 254 & 254 & 対称曲げ 2 次 \\
\hline
\end{tabular}

第 2 表 ロール弾性模型の振動特性（解析值)

\begin{tabular}{ccccl}
\hline \multirow{2}{*}{ 次数 } & \multicolumn{3}{c}{ 固有振動数 $[\mathrm{Hz}]$} & \multirow{2}{*}{ モード形状 } \\
\cline { 2 - 4 } & ばね $\mathrm{A}$ & ばね $\mathrm{D}$ & ばね無し & \\
\hline 1 & 21 & 40 & 0.5 & ロール弾性 \\
2 & 69 & 69 & 69 & 対称曲げ 1 次 \\
3 & 82 & 87 & 81 & 逆対称曲げ 1 次 \\
4 & 107 & 107 & 107 & 対称ねじり 1 次 \\
5 & 108 & 108 & 108 & 逆対称ねじり 1 次 \\
6 & 246 & 246 & 246 & 対称ねじり 2 次 \\
7 & 247 & 247 & 247 & 逆対称ねじり 2 次 \\
8 & 286 & 286 & 286 & 対称曲げ 2 次 \\
\hline
\end{tabular}

た .さらにマッハ数 $M$ を変化させるときに， $M=0.92$ ， 0.96 でフラッタが発生した .フラッタ抑制は, 支持装置の フラッタ停止機構を用いて行った . $M=0.6$, ロールばね $\mathrm{A}$ の場合について, 歪みの時間履歴を第 6 図に示す . 左側 はフラッタ発生からフラッタ停止までの履歴である . 右側 は午のフラッタ発生中の時間スケールを拡大した履歴であ る. 左右の歪みが逆対称となっており, 逆対称モードフラッ タであることがわかる .

2.3.2 フラッタ解析 フラッタは, 構造と非定常空気力 の連成問題として以前に提案した方法 ${ }^{6)}$ で解析する. 非定 常空気力は , 線形揚力面理論に基づく DPM で求めた . 線 形揚力面理論では逆対称モードと対称モードの非定常空気 力は分離できるため, 解析時間の短縮のために別々に求め た.解析に用いた固有モードは, 逆対称モードは 1 次・ 3 次 $\cdot 5$ 次 7 次モード, 対称モードは 2 次・ 4 次・ 6 次・ 8

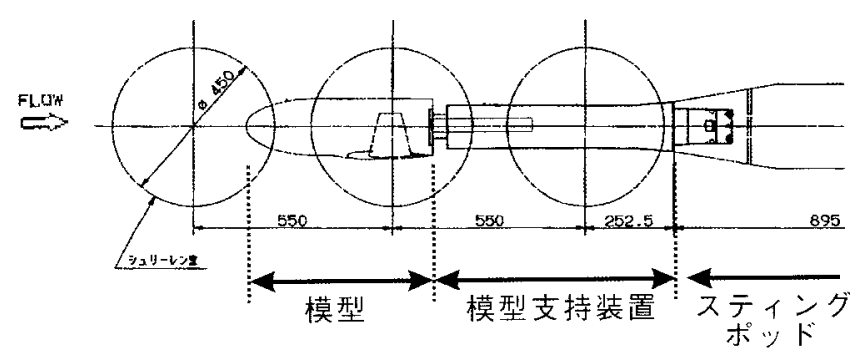

第 5 図 風洞へのロール弾性模型設置概要
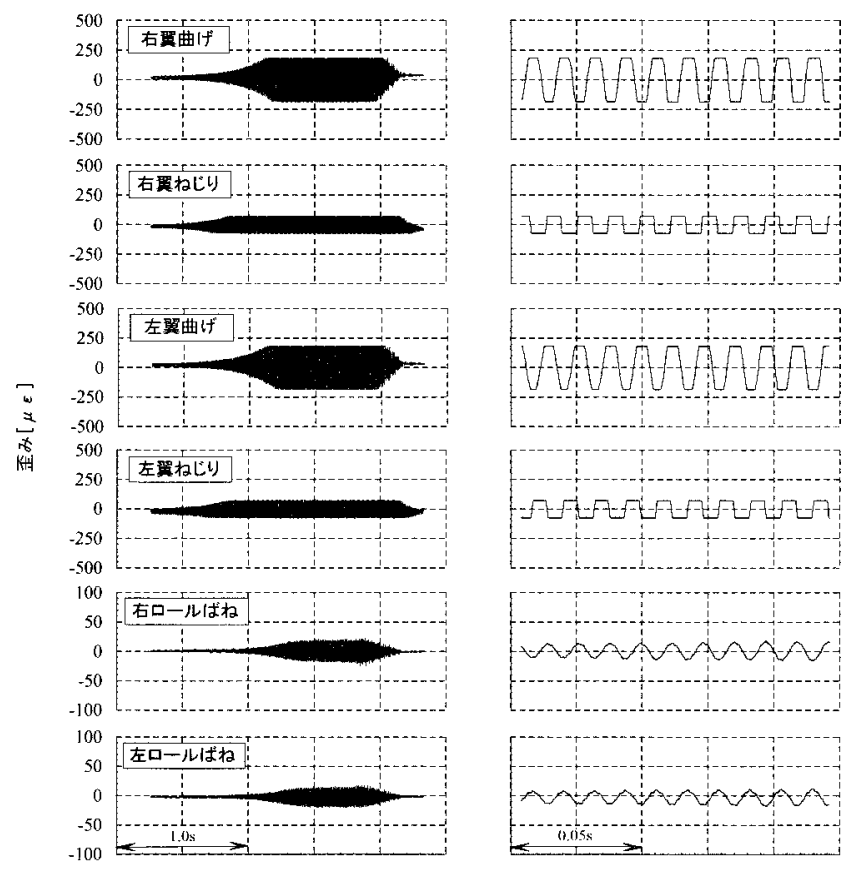

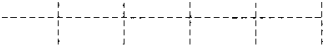
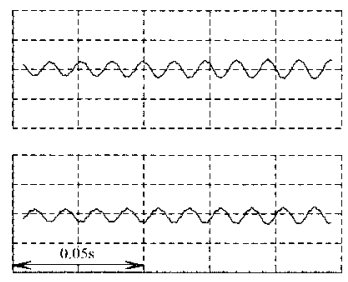

時間

第 6 図 逆対称モードフラッタ時間履歴

次モードである . 解析の対象としたマッハ数は $M=0.6$, $0.7,0.8,1.2,1.5$ である.空力面は, 左右の対称性を利 用して右半分のみのモデル (主翼部 60 要素・チップフィン 部 36 要素・胴体部 100 要素) を用いた (第 7 図). 


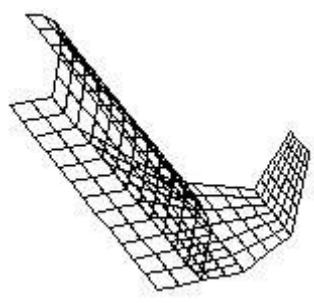

第 7 図 ロール弾性模型の空力モデル
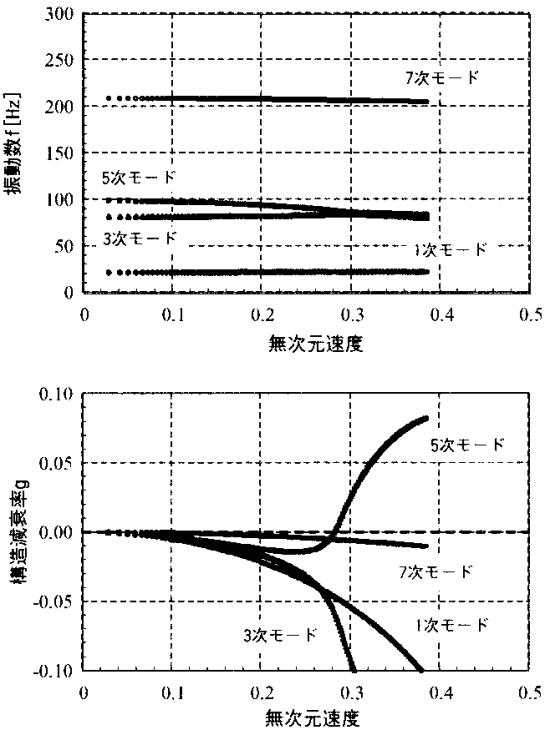

第 8 図 逆対称モードフラッタ解析

上記で求めた非定常空気力を用いて, $\mathrm{p}-\mathrm{k}$ 法によりフラッ 夕解析を行った .この際, 構造減衰率は一般的に用いられ ている $g=0.03$ を仮定した . 無次元フラッタ速度は, 理想 気体・定常非粘性・等エントロピーを仮定して次式 ${ }^{11)}$ で求 めた .

$$
\overline{U_{\mathrm{F}}}=\frac{1}{2 \pi f_{\alpha} b} \sqrt{\frac{\pi b S_{\mathrm{w}}}{2 m}} \sqrt{\frac{\gamma P_{0} M^{2}}{1+(\gamma-1) M^{2} / 2}}
$$

ここで $m$ は翼の質量， $b$ は翼根 $1 / 2$ コード長,$S_{\mathrm{w}}$ は翼面 積, $f_{\alpha}$ はねじりモード振動数, $\gamma$ は比熱比である.

結果，3 次モードと 5 次モードが連成する逆対称モード フラッタが, クリティカルなフラッタとして得られた . ま た， 2 次モードと 4 次モードが連成する対称モードフラッ タポイントも得られた .一例として $M=0.6$, ロールばね A のときの逆対称モードフラッタ解析結果を第 8 図に示す .

2.3.3 局所マッハ数計測とフラッタ解析補正 フラッタ 実験・解析の結果， $M=1.2$ においてフラッタ限界の実験値 が解析值よりもかなり高くなるという結果が得られた（第 9 図参照) . 同形状のチップフィン翼を用いた , 別のフラッ 夕実験 ${ }^{12)}$ でも同樣の現象が発生している．また磯貝ら ${ }^{13)}$ の実験でも, 詳しい解析は無いものの, 低超音速域で実験 值が上昇する結果が得られている. 現象は必ずしも同じと は言えないが, 我々の得た実験結果は, 一樣流マッ八数に 比へ胴体あるいはチップフィンの影響で, 翼面付近の局所

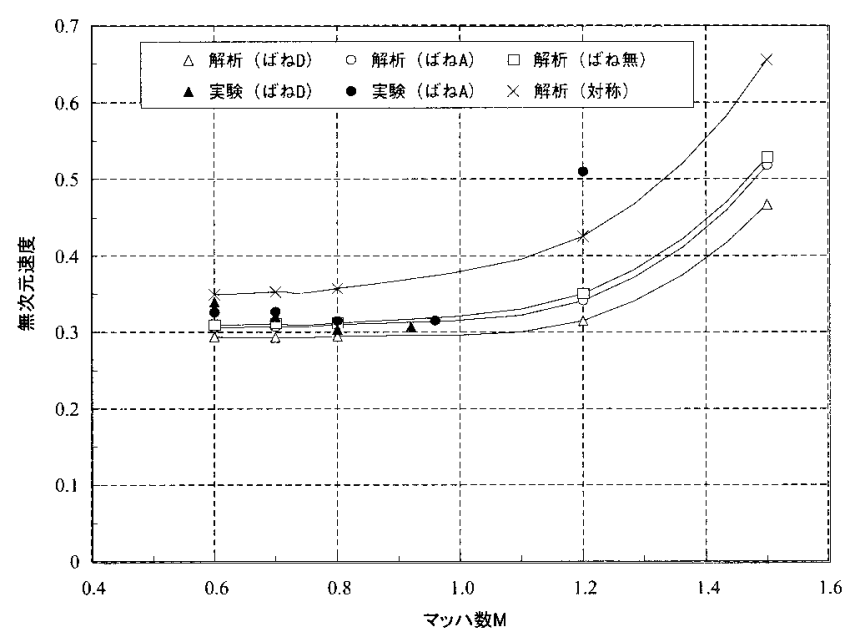

第 9 图 逆対称モードフラッタの無次元速度

マッ八数が大きく異なることが原因の一つではないかと推 察した . 乥こで同じ形状の模型 (7075-T651 の岡体模型) について遷音速風洞で局所マッハ数を計測し，ここから補 正マッ八数を求めてフラッタ解析の補正を試みた。

局所マッ八数の計測について述べる.マッハ数は直接計 測を行うことができないため, 1 次計測量として翼面の静 圧および近傍の総圧を計測し，乥こから局所マッハ数を計 算で求める. 翼面の静圧 $P_{1}$ は, 右主翼部に埋め込んだ 4 個 の圧力センサーにより計測する . 圧力センサ一位置は内舷 側の 2 個が翼根からスパン方向 $45.5 \mathrm{~mm}$ 位置であり，外舷 側の 2 個が同 $140.5 \mathrm{~mm}$ 位置である . 前縁側は, 内舷・外 舷ともにコード方向 $31.1 \%$ 位置 (最大翼厚部) であり，後 縁側は, 内舷が同 $90.7 \%$, 外舩が同 $81.5 \%$ 位置である.総 圧については, 機軸方向にトラバース可能な 2 本のピトー 管を設置して，クォーツマノメータにより各圧カセンサー 近傍を計測する．超音速流中では，ピト一管自身によって 発生する垂直衝撃波下流の総圧 $P_{02}$ が計測される . Pitot 管は, 右翼の圧力センサーと干渉が少なくなるように左翼 側に設置した (実際に, 静圧には Pitot 管の影響が無いこ とを確認した）. 2 本のスパン方向位置は, 翼面の圧力セン サーと同じ位置である.模型および Pitot 管設置状況を第 10 图に示す.計測は，気流 (一樣流) か設定した条件に整 定してから 30 秒経過した後の, 安定した総圧データを静 圧データとともに取り込む方法で行った、気流条件は，一 樣流マッハ数 $M=0.6,0.8,1.0,1.1,1.2,1.3,1.4$, , 樣流総圧 (集合胴圧) $P_{0}=80 \mathrm{kPa}, 100 \mathrm{kPa}$ とした 。

ここで局所マッハ数 $M_{1}$ と $P_{1}, P_{02}$ の関係は RankineHugoniot の関係式14) を基に次式で表される .

$$
\frac{P_{1}}{P_{02}}=\frac{P_{1}}{P_{2}} \frac{P_{2}}{P_{02}}=\frac{\left(\frac{2 \gamma}{\gamma+1} M_{1}^{2}-\frac{\gamma-1}{\gamma+1}\right)^{\frac{1}{\gamma-1}}}{\left(\frac{\gamma+1}{2} M_{1}^{2}\right)^{\frac{\gamma}{\gamma-1}}}
$$

Regula-Falsi 法により，計測で求めた $P_{1}, P_{02}$ を用いて局 所マッ八数 $M_{1}$ を算出した . 亜音速流中の局所マッハ数に 


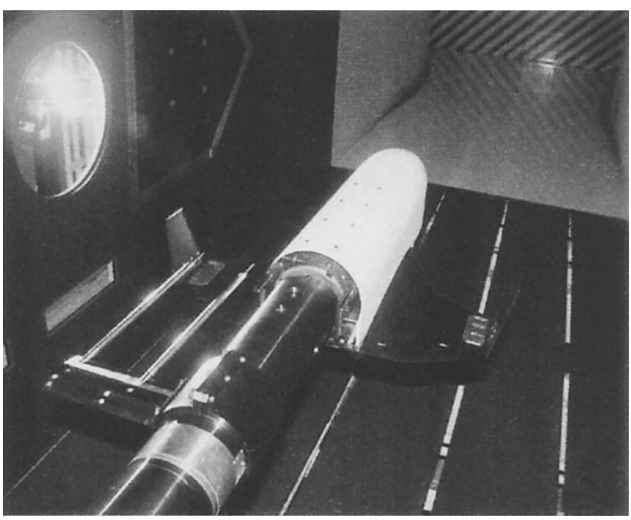

第 10 図 模型および Pitot 管設置状況

第 3 表 補正マッハ数

\begin{tabular}{cc}
\hline 一樣流マッハ数 & $\begin{array}{c}\text { 補正マッハ数 } \\
M\end{array}$ \\
\hline 0.6 & 0.68 \\
0.8 & 0.93 \\
1.0 & 1.30 \\
1.1 & 1.35 \\
1.2 & 1.46 \\
1.3 & 1.61 \\
1.4 & 1.76 \\
\hline
\end{tabular}

ついては次式で算出した .

$$
\frac{P_{1}}{P_{0}}=\left(\frac{1}{1+(\gamma-1) M_{1}^{2} / 2}\right)^{\frac{\gamma}{\gamma-1}}
$$

局所マッハ数 $M_{1}$ は各圧力センサー位置に対して求まる. ここで 3 次モードおよび 5 次モードがフラッタの連成モー ドであり, 主翼部外䑪側の変形量が大きい，つまり，非定 常空気力への影響も大きいということになる．乥こで補正 マッ八数 $M^{\prime}$ は, 主翼部外舷側 2 力所の局所マッハ数の算 術平均值として求めた (第 3 表). 得られた補正マッ八数 $M^{\prime}$ をDPM に適用することでフラッタ解析の補正を行っ た . 補正を行った無次元フラッタ速度 $\overline{U_{F}}$ を第 11 図に示す．

2.3.4 フラッタ特性の考察 実験および解析結果ともに 逆対称モードフラッタがクリティカルであり, 対称モード フラッタよりもフラッタ速度が低い .この逆対称モードフ ラッタは, 3 次モードと 5 次モードが連成して発生するこ とが解析からわかった .

ロール弾性のフラッタへの影響を考える．ロールフリー (ばね無し) の場合には，もともと逆対称モードフラッタが クリティカルである . ロール弾性が存在するとこのフラッ 夕速度が低下し, ロール弾性特性が変化するとフラッタ速 度も変化する.ロール弾性特性の変化は, 1 次モードと 3 次モードの振動特性に顕著に現れる．つまり，ロール弾性 によるフラッタ速度の変化の直接原因は, これらのモード の振動特性の変化であると考えられる .

マッ八数 $M=1.2$ におけるフラッタ解析值と実験值の 相違について述べる. 通常の解析では, 実験值が解析値よ りもかなり高い值を示した . しかし補正マッ八数を用いた

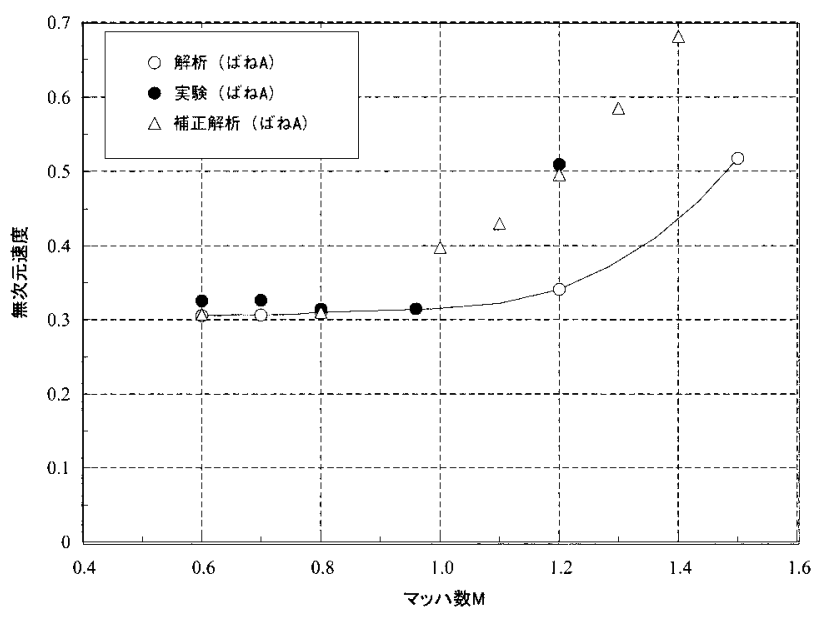

第11図 逆対称モードフラッタの無次元補正速度

解析結果は，実験値と良く一致した。つまり相違の原因は， 局所マッ八数が一樣流マッ八数よりも増加したためと考え られる.特に超音速領域では, マッ八数に対するフラッタ速 度の変化が大きいため, 相違か顕著であったと考えられる

\section{3. ヨー弾性モードの影響}

ヨー弾性モードか影響するフラッタ特性について述べる。 HOPE-X では当初チップフィン形態翼が計画されていた . チップフィンの気流迎角は，ヨー弾性モードにより大きく 変化する.この場合, 大きな非定常空気力が翼に作用し, フ ラッタ特性に影響することが考えられる．平面翼の場合で も，ヨー弾性モードが連成したと思われるフラッタ現象が 風洞実験で得られている6).

フラッタ特性を調ベるため, チップフィン形態翼全機模 型により風洞実験を行った .ヨー弾性モードを有する特殊 なスティング型支持装置を用いて，打ち上げ形態における 結合部の影響を模擬した .ここではさらに模型にもロール 弾性モードをもたせて, 模擬する結合部自由度を増やして いる.フラッタ解析も併せて行った 。

\section{1 支持装置と 全機模型}

3.1.1 支持装置 支持装置は, ピッチ方向の自由度を有 する支持装置 ${ }^{5,6)} 90^{\circ}$ 回転させたものである . 風洞模型 支持装置の機構概要を第 12 図に示す. $\exists$ 一方向弾性は, 支 持装置内部の板ばねの曲け弾性により模擬される . 模型は この板ばねの先端に取り付けられる．なお板ばねには，フ ラッタ計測用に歪みゲージを貼付してある .

ヨー弾性特性を変化させる機構を有している．板ばねは 前方支持部 (回転支点) と後方支持部 (すべり支点) で支持 され，後方支持部はサーボモータて移動可能である.支持部 間距離力変化することで, 板ばねの曲け弾性特性か変化する ため, 結果としてヨー弾性特性か変化する.ヨーばね弾性特 性を前方支持部まわりの回転岡性 $K$ で表すと， $K=20000$ から $50000 \mathrm{Nm} / \mathrm{rad}$ まで変化する.

この機構はフラッタ停止の役割も担っている.ヨー弾性 モードの特性を変化させることで, このモードが連成する フラッタ特性か変わり，フラッタを停止できる． 


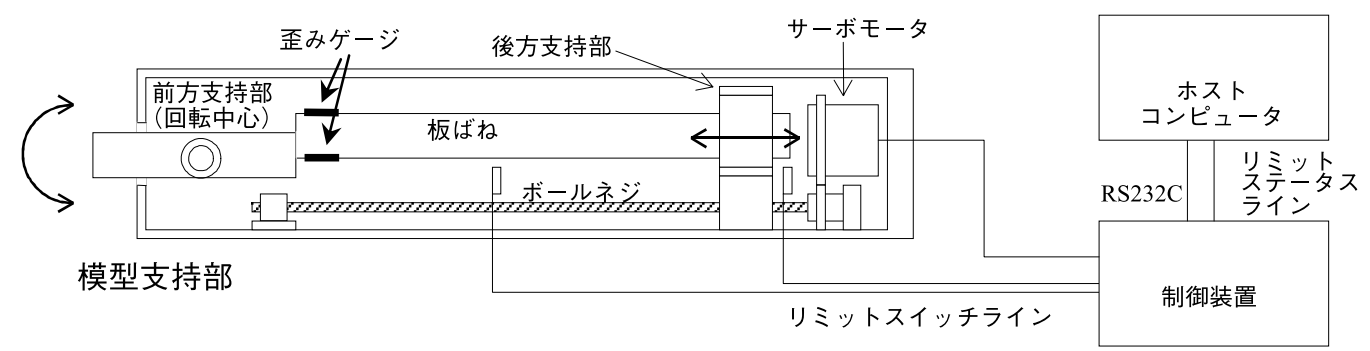

第 12 図 $\exists$ 一弾性支持機構

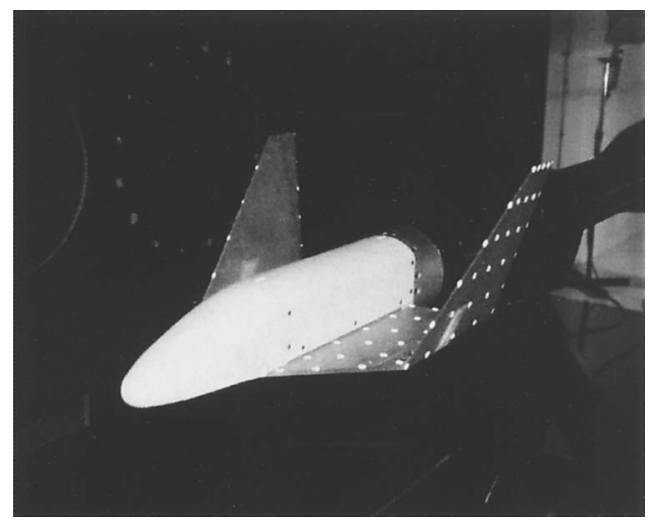

第13図 ヨー弾性模型

3.1 .2 全機模型 全機模型 (ヨー弾性模型) を第 13 図に 示す. 翼は主翼部とチップフィン部から構成される . ヨー 弾性モードの連成を検討する目的で, チップフィン部を相 対的に大きくした . 左右の主翼根には曲げおよびねじり計 測用の歪みゲージを貼付した .

胴体部は長さ $450 \mathrm{~mm}$ (スカート部除く), 高さ・幅と も $86.8 \mathrm{~mm}$ である . 主翼部 $5 \mathrm{~mm}$ 厚, チップフィン部は $2 \mathrm{~mm}$ 厚の 7075-T651 の板翼である . 主翼部のスパン長は $100 \mathrm{~mm}$, コード長は翼根で $300 \mathrm{~mm}$, 翼端で $220 \mathrm{~mm}$ であ る .チップフィン部はキャント角 $14^{\circ}$, スパン長は $204 \mathrm{~mm}$ ， 翼端コード長は $60 \mathrm{~mm}$ である . 主翼部とチップフィン部の 結合部後方に $50 \%$ コード位置までスリットが入っている . 質量は片翼で $0.52 \mathrm{~kg}$ である.

模型にはロール方向自由度も与えている．これは模擬す る結合部自由度を増やすためである.ベアリングを用い て模型にロール方向自由度を与え, さらにロールばね（板 ばね）によりロール弾性を与えている．ロールばね岡性は $250 \mathrm{Nm} / \mathrm{rad}$ である . ばねには歪みゲージを貼付した .

\section{2 振動特性}

3.2.1 振動試験 動的変位計測システムを用いて振動試 験を行った. 計測点は 117 点 (胴体部 8 点, 左右翼光れ光 れ 54 点, 加振部 1 点) である. 動電型シェーカーにより， 主翼部の 1 点ランダム加振を行った .ただしヨー弾性モー ドは, シェーカーによる加振が主翼面に垂直方向のため, 励 起されにくい，光こでハンマーインパクト法により，ヨー 弾性モードの固有振動数を別途計測した .

3.2.2 振動解析 FEM による振動解析を行った . 振動 解析に用いた FEM モデルは, 主翼部・チップフィン部と
第 4 表 $\exists$ 一弾性模型の振動特性

\begin{tabular}{cccl}
\hline \multirow{2}{*}{ 次数 } & \multicolumn{2}{c}{ 固有振動数 $[\mathrm{Hz}]$} & \multicolumn{1}{c}{ モード形状 } \\
\cline { 2 - 3 } & 試験值 & 解析值 & \multicolumn{1}{c}{ ロール弾性 } \\
\hline 1 & 18 & 19 & 年 \\
2 & 29 & 28 & TipFin 対称曲げ 1 次 \\
3 & 33 & 32 & TipFin 逆対称曲げ 1 次 \\
4 & 56 & 56 & ヨー弾性 \\
5 & 108 & 102 & TipFin 対称ねじり 1 次 \\
6 & 108 & 102 & TipFin 逆対称ねじり 1 次 \\
7 & 137 & 141 & TipFin 対称曲げ 2 次 \\
8 & 166 & 164 & TipFin 逆対称曲げ 2 次 \\
9 & - & 170 & TipFin 対称高次 \\
\hline
\end{tabular}

第 5 表 $\exists$ 弾性モードの振動特性

\begin{tabular}{|c|c|c|}
\hline \multirow{2}{*}{ 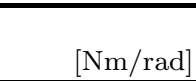 } & \multicolumn{2}{|c|}{ 固有振動数 $[\mathrm{Hz}]$} \\
\hline & 試験値 & 解析値 \\
\hline 20000 & 45 & 45 \\
\hline 25000 & 49 & 49 \\
\hline 30000 & 50 & 50 \\
\hline 35000 & 52 & 52 \\
\hline 40000 & 54 & 54 \\
\hline 45000 & 56 & 56 \\
\hline 50000 & 58 & 58 \\
\hline
\end{tabular}

もにシェル要素である . ロール弾性モードおよびヨー弾性 モードについては, 実機構を关のままモデル化することは 少々複雑である. 炎こで, ロール弾性モードはビーム要素 のねじり弾性，ヨー弾性モードは回転ばね弾性で模擬した。

3.2 .3 振動特性の考察 ヨーばね岡性 $K=45000 \mathrm{Nm} /$ $\operatorname{rad}$ のケースでの振動特性を第 4 表に示す . また，ヨ一弾 性モード (4 次モード) の固有振動数について，ヨーばね 岡性を変化させたときの試験值と解析值を第 5 表に示す.

試験と解析結果を比較すると，5 次以上の高次モードの 固有振動数に $5 \%$ 程度の相違が見られる.しかしこの程度の 相違は誤差の範囲内であり, 全体として固有モード形およ び固有振動数の一致は良好である . フラッタ解析には, 解 析固有モード形と実験固有振動数を用いた .

\section{3 フラッタ特性}

3.3.1 フラッタ実験 遷音速風洞においてフラッタ実験 を行った . 風洞への模型設置概要を第 14 図に示す．実験は マッハ数 $M=0.6,0.7,0.8$ で, 総圧 $P_{0}$ を低い值から徐々 に加圧する方法である .この方法でクリティカルなフラッタ を得た 、フラッタ抑制は, ヨーばね岡性を変えることで行っ た .マッハ数 $M=0.6$, ヨーばね剛性 $K=45000 \mathrm{Nm} / \mathrm{rad}$ のケースにおける歪みの時間履歴を第 15 図に示す. 左側 


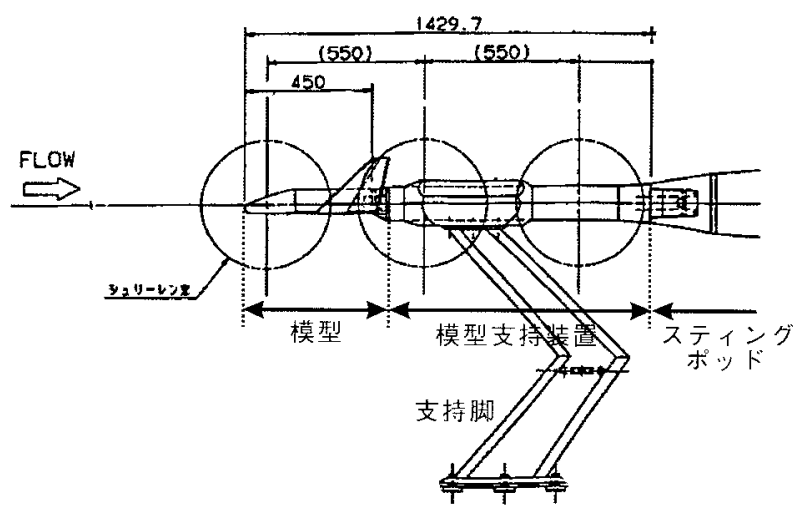

第 14 図 風洞へのヨー弾性模型設置概要

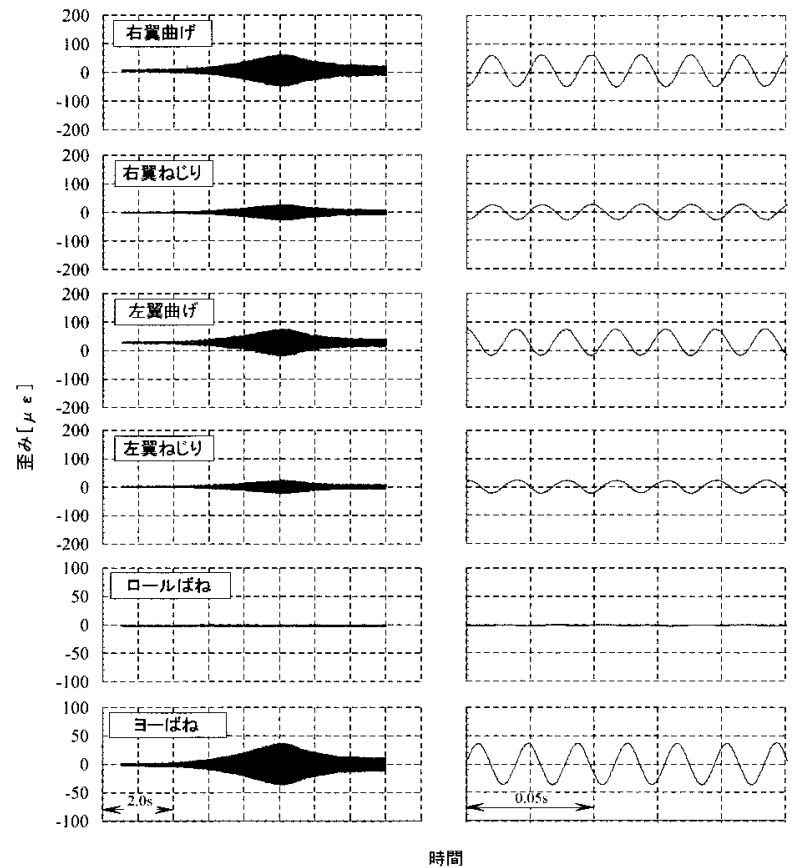

第15図 ヨーイングモードフラッタ時間履歴

はフラッタ発生からフラッタ停止までの履歴である . 右側 は光のフラッタ発生中の時間スケールを拡大した履歴であ る .ヨーばね歪みが大きく, 左右の歪みが逆対称である . ま たヨーばね岡性を変化させるとフラッタが収まることから， このフラッタはヨーイングモードフラッタであると考えら れる.

フラッタポイントの確定は困難であった . 理由の一つは， 支持装置機構 (板ばね支持部の移動機構) を用いてヨーば ね岡性を変化させた後に元の岡性に戻すと，フラッタが発 生する総圧 $P_{0}$ か変化したためである .もう一つは, 振動が 発散し乥うでしないことが多く, フラッタ判別が難しかっ たためである．これらの原因としては，フラッタが構造減 衰に敏感であり, 支持部移動により構造減衰率が変化する ためと考えられる . 最終的には同じ条件の実験を複数回行 い, 弚の代表值をフラッタポイントとして確定した .

3.3.2 フラッタ解析 フラッタ解析を行った. 解析手法 は, 2.3 .2 節で示した方法と同樣である. 空力面は右半分の

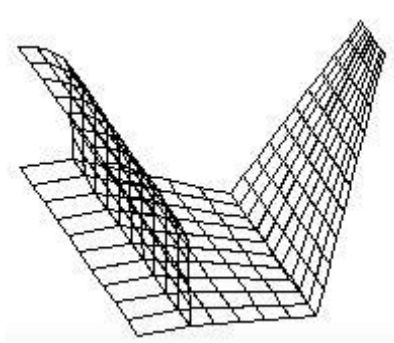

第16 図 ヨー弾性模型の空力モデル
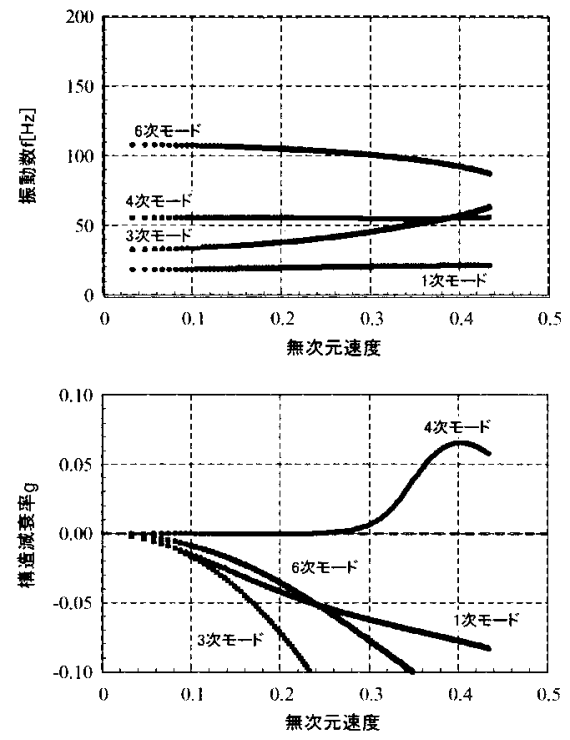

第17図 ヨーイングモードフラッタ解析

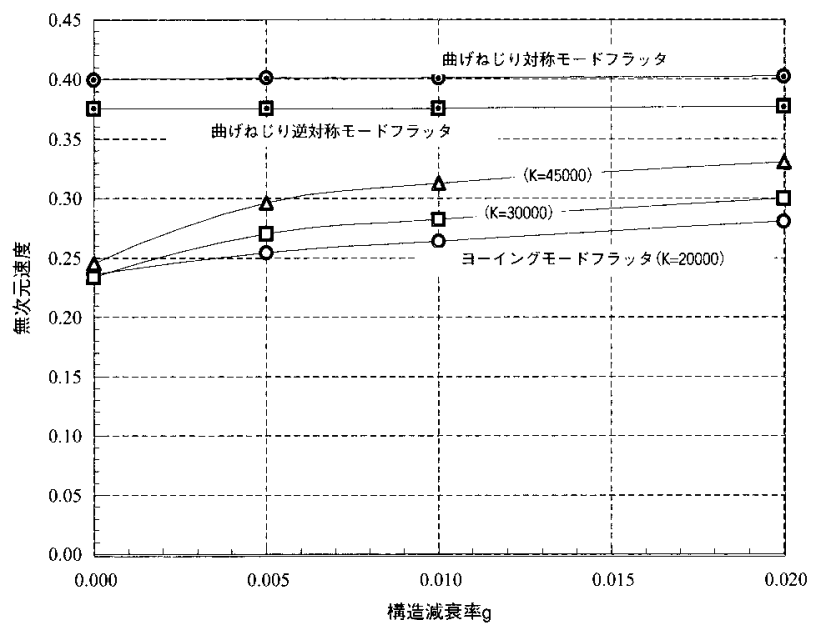

第 18 図＼cjkstart無次元フラッタ速度の構造減衰率変化

モデル (主翼部が 50 要素, チップフィン部が 100 要素, 胴 体部 90 要素) を用いた (第 16 図). 解析に用いた固有モ一 ドは, 逆対称モードが 1 次・ 3 次・ 4 次・ 6 次, 対称モード は 2 次・ 5 次 7 次 9 次である. 構造減衰率は $g=0.0$, $0.005,0.01,0.02$ について解析した。

解析の結果，(1) ヨー弾性モードが連成するフラッタ (以 下, ヨーイングモードフラッタと呼ぶ); 3 次と 4 次モードの 連成, (2) 曲げねじり対称モードフラッタ ; 2 次と 5 次モー 

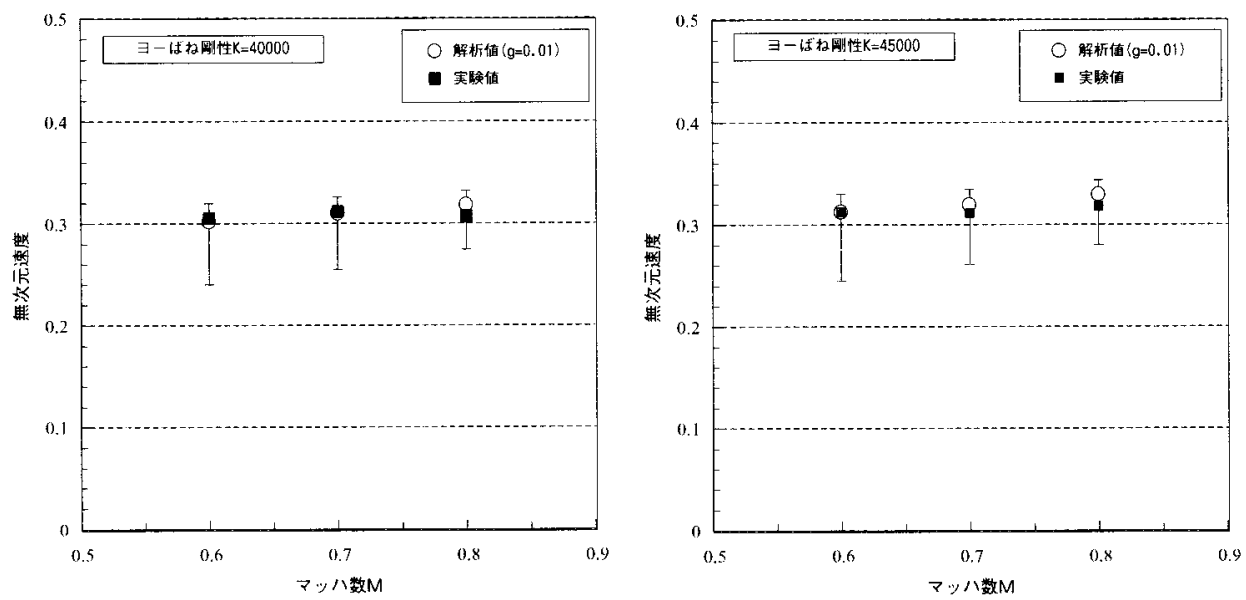

第19図 ヨーイングモードフラッタの無次元速度

ドの連成 , (3) 曲げねじり逆対称モードフラッタ ; 3 次と 6 次モードの連成，以上の 3 種類のフラッタが求められた . 一例として $M=0.6$ ，ヨーばね岡性 $K=45000 \mathrm{Nm} / \mathrm{rad}$ におけるヨーイングモードフラッタの解析結果を第 17 図 に示す . また $M=0.6$ のケースについて , 無次元フラッタ 速度の構造減衰率による変化を第 18 図に示す.曲げねじり 対称モードフラッタと曲げねじり逆対称モードフラッタは， 構造減衰率 $g$ か変化しても光れほどフラッタ速度が変化し ない.しかしヨーイングモードフラッタは, $g$ の值により フラッタ速度が大きく異なり, 構造減衰率に非常に敏感で ある .

3.3.3 フラッタ特性の考察 実験・解析で得られたヨーイ ングモードフラッタポイントを，ヨーばね岡性 $K=40000$ および $45000 \mathrm{Nm} / \mathrm{rad}$ のケースについて第 19 図に示す.解 析值は構造減衰率 $g=0.01$ である. 併せて垂直線で $g=$ 0.00〜0.02 の值についても示す.垂直線の最小值が $g=0.00$ のとき，最大值が $g=0.02$ のときである .

実験結果と解析結果を比較する. 支持装置機構に起因し て構造減衰率が変化すると考えられ，厳密な定量的比較は 難しいが， $g=0.01$ の場合に実験值と解析值が近くなる. 両者ともに，ヨーイングモードフラッタがクリティカルに なり，ヨーばね岡性によりフラッタ速度か変化する．また， フラッタ速度は構造減衰率に敏感である．以上から，実験 と解析は良く一致していると考えられる．

\section{4. 結論}

有翼宇宙往還機の打ち上げ形態における，結合部の弾性 モードのフラッタへの影響を調べた . 結合部弾性モードを ロール弾性モードおよびヨー弾性モードとして模擬し，フ ラッタ実験およびフラッタ解析を行った 。

ロール弾性モードを振動特性に含めた解析・実験の結果， 逆対称曲げねじりフラッタがクリティカルになった . ロール 弾性モードは光のフラッタ特性に影響し，フラッタ速度を 低下させることがわかった，一方，ヨー弾性モードが連成 するフラッタ (ヨーイングモードフラッタ) がクリティカル になった .ヨーイングモードフラッタは, ヨー弾性モードと
チップフィンの逆対称曲げ 1 次モードとが連成するフラッ タであり，構造減衰率に非常に敏感であることがわかった． 以上より，ロール弾性やヨー弾性モードが影響するフラッ 夕特性を解明することができた .これらのフラッタはクリ ティカルになる可能性があることがわかった .つまり HOPE$\mathrm{X}$ のように, 機体がロケットに搭載されて打ち上げられる 形態では , 結合部の弾性モードが影響するフラッタを考慮 する必要があると考えられる．

\section{参 考 文 献}

1) Perry III, B. and Cole, S. R.: Summary of an Active Flexible Wing Program, J. Aircraft, 32 (1995), pp. 10-15.

2) Soistmann, D. L. and Spain, C. V.: An Experimental and Analytical Study of a Lifting-Body Wind-Tunnel Model Exhibiting Body-Freedom Flutter, AIAA Paper 93-1316, 1993.

3) Chen, G. S. and Dugundji, J.: Experimental Aeroelastic Behavior of Forward-Swept Graphite/Epoxy Wings with RigidBody Freedom, J. Aircraft, 24 (1987), pp. 454-462.

4) Niblett, L. T.: The Fundamentals of Body-Freedom Flutter, Aeronaut. J., 90 (1986), pp. 373-377.

5) Kanda, A. and Ueda, T.: Wind Tunnel Tests and Analysis on Flutter of Spacecraft Including Pitching Effects in Its Launching Configuration, International Forum on Aeroelasticity and Structural Dynamics, Williamsburg, Virginia, 1999, pp. 115-120.

6) 神田 淳, 上田哲彦 : 有翼機の単独飛行/打ち上げ形態における フラッタ特性と風洞模型支持法の開発，日本航空宇宙学会論文集， 49 (2001), pp. 346-353.

7) Ueda, T.: Unsteady Aerodynamic Calculations for General Configurations by the Doublet-Point Method, NAL TR$1101 \mathrm{~T}, 1991$.

8）神田 淳, 上田哲彦: ロール自由度制御機構を有するスティング 支持装置，NAL TR-1335, 1997.

9) 外㟝得雄, 上田哲彦: 動的変位計測装置と振動予備試験, NAL TM-683, 1995.

10) 神田 淳, 外㟝得雄 : 動的変位計測システムの更新, NAL TM$748,2000$.

11) Bisplinghoff, R. L. and Ashley, H.: Principle of Aeroelasticity, John Wiley \& Sons, 1962 , pp. 235-258.

12）神田 淳, 上田哲彦: 有翼宇宙往還機型全機模型の逆対称モード フラッタ, NAL TR-1342, 1997.

13）磯貝紘二, 江尻宏, 菊池孝男, 中道二郎, 野口義男, 森田甫之: 複合材平板を芯材にした後退翼フラッタ模型の遷音速フラッタ試 験 (空力弾性テーラリング効果の検討)， NAL TR-827, 1984.

14）相原康彦 : 流れの力学, 培風館, 東京, 1990, pp. 33-42. 